\title{
Bacillus in the guts of honey bees (Apis mellifera; Hymenoptera: Apidae) mediate changes in amylase values
}

\author{
Miao WANG ${ }^{1,2}$, Wen-Zheng ZHAO ${ }^{2}$, Hong XU², Zheng-Wei WANG ${ }^{3, *}$ and ShaO-Yu HE ${ }^{2, *}$ \\ ${ }^{1}$ Plant Protection College, Yunnan Agricultural University, Kunming 650201, China; ynbee@163.com \\ ${ }^{2}$ Eastern Bee Research Institute, Yunnan Agricultural University, Kunming 650201, China; rurosezwz@163.com; \\ 635219202@qq.com; kmhsy@163.com
}

${ }^{3}$ Key Laboratory of Tropical Forest Ecology, Xishuangbanna Tropical Botanical Garden, Chinese Academy of Sciences, Kunming, China; wangzhengwei@xtbg.ac.cn

Key words. Hymenoptera, Apis mellifera, gut microbe, Bacillus, amylase value, honey bee nutrition

\begin{abstract}
Amylase is one of three main enzymes involved in the breakdown and utilization of macromolecules. In honey bees (Apis mellifera), amylase was traditionally believed to originate only as secretion of the bee. However, other sources of amylase production, such as microbes in the guts of bees remained to be studied. In our research, we compared the differences in the amylase values in rape flower nectar and honey in the stomachs of bees. Then, culture-dependent and culture-independent (16sDNA) methods were used to isolate and identify bacteria in rape flower nectar and bee stomach honey. The dominant bacteria were added to nectar, and the amylase values of nectar with added gut microbes and nectar without added microbes were compared. Our findings indicate that the amylase value was significantly increased, which correlates with the increase in number of bacteria that occurred from nectar to honey in the stomachs of bees. The dominant bacteria in honey bee stomachs were mainly Bacillus during the flowering season of rape. Experiments confirmed that the amylase levels in nectar increased significantly when bacteria were added. These results indicate that bacteria in the foregut of bees help in the processing floral nectar into honey.
\end{abstract}

\section{INTRODUCTION}

Amylase is one of an organism's three main enzymes (i.e. amylase, protease and lipase) (Howell, 1985). Honey bees mainly consume nectar and pollen collected from plants. Within their nest, young worker bees' process nectar and pollen into honey and bee bread, respectively, and store these in special areas of the comb. Honey is the main source of carbohydrates for bees and bee bread their main source of protein, vitamins and other nutritional components (Winston, 1987). Amylase helps to digest carbohydrates, while protease and lipase digest bee bread into amino acids and lipids, which bees can absorb (Howell, 1985).

Rinaudo et al. (1973) compared the properties and characteristics of honey bee food glands, including nectar and honey amylase. Their results indicate that honey amylase is secreted by honey bee food glands, rather than obtained from pollen and nectar. They also suggest that the amylase in honey may share the same origin. Consequently, since this discovery, honey amylase is widely considered to be of animal origin. However, in recent years, due to amylases being important and popular for use in presentday biotechnology, research has indicated that amylases can come from several other sources, such as plants and micro-organisms (Gupta et al., 2003). Until recently, there has been very little work on the involvement of gut microorganisms in bee nutrition. Lee et al. (2014) studied the contribution of the microbial community to food process- ing in the honey bee and based on an analysis of metatranscriptomes identified three major bacterial classes active in the gut (gamma-Proteobacteria, Bacilli, and Actinobacteria), which they predicted were likely to participate in the breakdown of complex macromolecules (e.g. Polysaccharides and Polypeptides).

Amylase producing micro-organisms are widely distributed in nature (Sun et al., 2010). These micro-organisms include fungi, yeasts and bacteria. Among them, Aspergillus sp., Rhizopus sp. and Bacillus sp. are apparently the most common. In a previous study we showed that Bacillus sp. commonly occur in the stomach of honey bees, with Bacillus amyloliquefaciens and Bacillus subtilis the most dominant bacteria in bees foraging for food from rape flowers (Wang et al., 2014). Bacilli are able to produce enzymes and B. amyloliquefaciens can produce amylase, lipase, and protease, which catalyze the degradation of the principal chemical components in residues in drains, such as grease, proteins and starches (Snyder, 2009). Bacillus subtilis also produces amylase (Sun et al., 2010).

Floral nectar is not a suitable bacterial habitat due to its high osmotic pressure and the antimicrobial properties of secondary metabolites (Fridman et al., 2012), but it does contain some microorganisms, such as fungi and yeasts (Herrera et al., 2008, 2009, 2013; Pozo et al., 2011) and some bacteria (Gilliam et al., 1983; Gilliam, 1997; Fridman et al., 2012; Wang et al., 2014). The micro-organisms in floral nectar may moderate its temperature or chemical

\footnotetext{
* Corresponding authors.
} 


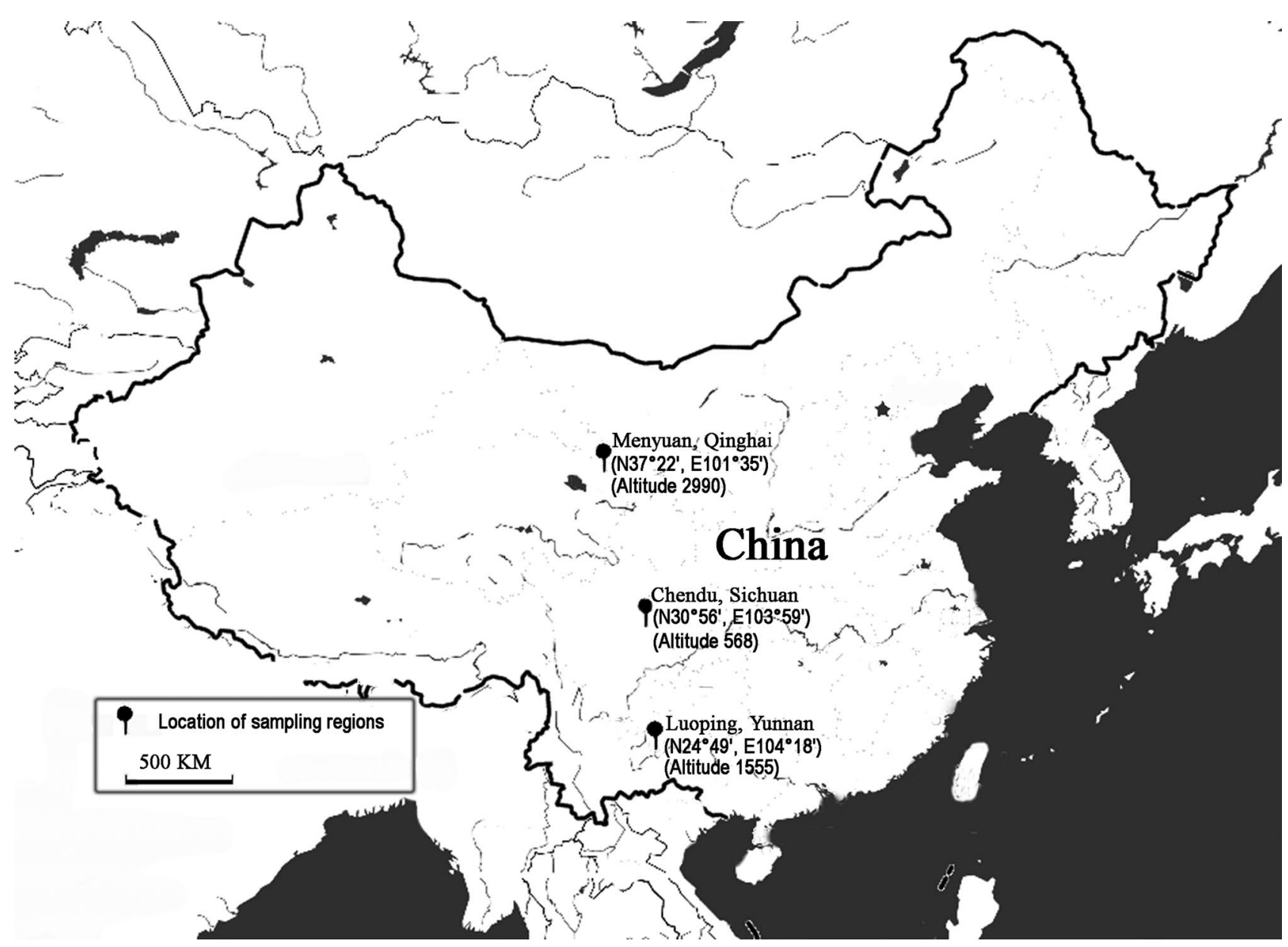

Fig. 1. Map of China showing the locations of the three rape growing areas at different altitudes at which rape flower nectar and honey bees were sampled.

profile and affect the attraction-repulsion relationships between plants and pollinators (Herrera \& Pozo, 2010; Fridman et al., 2012). The extent to which the bacteria in nectar affect bee amylase production is still unknown.

We hypothesized that some of the microbes in the gut of bees aid them in processing their food. Consequently, in this study, we first determined the changes in amylase values that occur during the conversion of rape (Brassica napus L.) nectar into honey in bee stomachs. Then, we used culture-dependent and culture-independent methods to compare the bacterial flora in nectar and stomach honey. Later, the dominant bacteria were added to nectar, in order to determine whether they can increase its amylase values. The relation between changes in microbe and amylase values from nectar to honey may help us better understand if these microbes do or do not contribute to the digestion of sugars by bees.

\section{MATERIAL AND METHODS}

\section{Nectar and bee samples}

Oilseed rape (B. napus L.) is one of the main oil producing plants around the world and is easily cultivated. In the present study, we collected nectar from rape flowers at three different locations (Fig. 1) at different latitudes and altitudes in China (Yunnan Province, 1,555 m; Sichuan Province, $568 \mathrm{~m}$ and Qinghai Province, $2,990 \mathrm{~m}$ ). At the same time, honey bee workers (Apis mellifera L.) were also collected to harvest their honey sac for subsequent examination. Three bee colonies at each location were randomly chosen from nearby apiaries, which were located in areas surrounded by rape fields from which pure rape honey was being harvested for sale by beekeepers.

\section{Nectar collection}

Rape floral nectar was collected using a sterile capillary when the rape fields next to apiaries were in full bloom. About $3.6 \mathrm{~mL}$ of nectar was collected at each location. Due to the different altitudes and environments at the three sites, the volume of nectar varied [i.e. nectar was collected from 3,924 flowers at Luoping, Yunnan Province (LP), 4,590 flowers at Chengdu, Sichuan Province (CD) and 9,450 flowers at Menyuan, Qinghai Province (MY)]. The nectar collected at each location was divided into three parts, the first $3 \mathrm{~mL}$ was used for isolating bacteria, the second $0.3 \mathrm{~mL}$ was used to determine its amylase value and bacteria were added to the last $0.3 \mathrm{~mL}$, which was then tested for its amylase value. The nectar used for isolating bacteria was stored at $4^{\circ} \mathrm{C}$, then immediately transported back to the laboratory where the isolation of bacteria was completed within two weeks of collecting the nectar. The nectar used for the amylase analysis was stored at $-20^{\circ} \mathrm{C}$ and the analysis finished within two weeks of collecting the nectar.

\section{Collection of honey from the stomach of bees}

Three healthy bee colonies were used at each of the three locations (LP, CD, and MY) and three samples were collected from each colony. Each sample consisted of 10 fully-loaded foragers, 
caught as they alighted on the landing board at the entrance of a hive. Worker bees sampled from each colony were immersed in $75 \%$ ethanol for $1 \mathrm{~min}$ to sterilize their surface and then rinsed three times with sterile water. The bees were dissected with sterile scissors in an aseptic box, the honey stomachs removed and directly put in a tube that contained $1 \mathrm{~mL}$ of sterile physiological saline $(0.9 \% \mathrm{w} / \mathrm{v} \mathrm{NaCl}, 0.1 \% \mathrm{w} / \mathrm{v}$ Tween 80 , and $0.1 \% \mathrm{w} / \mathrm{v}$ peptone) (Olofsson \& Vásquez, 2008). Three samples from a colony at one location were stored at $4^{\circ} \mathrm{C}$ in an icebox for subsequent isolation of bacteria.

For amylase analyses, another 6-25 bees from one colony were dissected as above and stomach honey was collected using a sterile syringe $(1 \mathrm{~mL})$ of which $0.3 \mathrm{~mL}$ was used to determine its amylase value. The same storage methods were used as described above; three colonies were sampled at each of the three locations (LP, CD and MY).

\section{Amylase analysis}

Nectar and stomach honey collected at the different locations were used for amylase determinations, which were carried out using an enzymatic-spectrophotometric method and a Shifeng Kit SFE90183 (Shi Feng Biotechnology Co., Ltd, Shanghai, China), which is a modified Phadebas Kit (Gangwar et al., 2010). We used the following procedure: substrate buffer $0.5 \mathrm{ml}$, water bath preheating for $5 \mathrm{~min}$ at $37^{\circ} \mathrm{C}$, added $0.1 \mathrm{~mL}$ sample, water bath reaction for $7.5 \mathrm{~min}$ at $37^{\circ} \mathrm{C}$, added $0.5 \mathrm{~mL}$ of liquid iodine and finally $3 \mathrm{~mL}$ of distilled water. OD value (absorbance) was determined using a spectrophotometer (722 s, Shanghai Precision \& Scientific Instrument Co., Ltd, China) at a wavelength of 600 $\mathrm{nm}$ and a $1 \mathrm{~cm}$ optical path. The formula used for calculating the amount of amylase was:

$\operatorname{AMS}(\mathrm{U} / \mathrm{dl})=\frac{\text { Blank OD }- \text { Determination OD }}{\text { Blank OD }} \times \frac{0.4 \times 0.5}{10} \times \frac{30 \mathrm{~min}}{7.5 \mathrm{~min}} \times \frac{100}{0.1} \times$ Dilution ratio

\section{Isolation and identification of Bacillus sp. from nectar and} stomach honey

Isolation:

Nectar and stomach honey (asepsis grinding) were, first, diluted with sterile water. Bacteria were isolated and cultured on Tryptone soy broth (TSB) agar media (Engel et al., 2013) using the spread plate method at $37^{\circ} \mathrm{C}$ for $48 \mathrm{~h}$. We selected 30 colonies with different morphologies from the surface of each plate, on which there were 30-300 colonies, and sub-cultured these to obtain pure isolates.

\section{Identification:}

A combination of molecular sequencing and culturing methods were used to identify the Bacillus in the samples of nectar and stomach honey, respectively.

Molecular sequencing method: 30 colonies of the dominant bacteria were selected for molecular identification, using $16 \mathrm{~S}$ rDNA as in previous studies (Olofsson \& Vásquez, 2008).

Culturing method: Initially a Gram strain of Bacillus was grown and sporulated in liquid Difco Sporulation Medium and the spores purified as described previously (Henriques et al., 1995). We used API 50CHB (bioMerieux) to detect Bacillus and determine similar species.

\section{Bacillus experiments}

To determine if bacteria in a bee's stomach have an effect on amylase values in nectar, we obtained pure cultures from TSB and inoculated the same concentration in terms of $\mathrm{CFU} / \mathrm{mL}$ of bacteria $(100-350 \mu \mathrm{L})$ recorded in stomach honey into to $5 \mathrm{~mL}$ of nectar. The exact volume of each sample was calculated based on the results from 2.3. Nectar samples $(5 \mathrm{~mL})$ to which bacteria

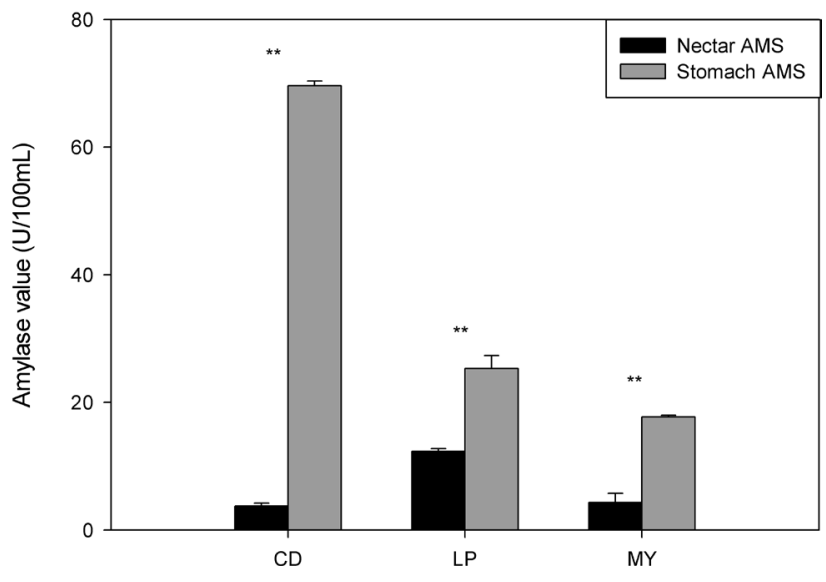

Fig. 2. Comparisons of amylase values recorded in nectar (black bar) and stomach honey (grey bar) at the three sites sampled (CD, LP and MY). ** - significant difference at $\mathrm{P}<0.01$.

were not added were used as the controls. All these samples were analyzed for amylase as described above.

\section{Statistical analyses}

The amylase values in floral nectar, gut honey, control nectar and nectar with added Bacillus were tested using one-way ANOVA to determine whether it differed depending on the location at which they were collected. Univariate ANOVAs were used to compare the changes in amylase values of floral and gut nectar, and nectar and nectar with added Bacillus, respectively, with the group and location effects used as fixed factors. We used a post hoc test (least significant differences, LSD) to determine whether there were significant differences between the different groups. All calculations were done using SPSS 19.0 (www.spss-china. com).

\section{RESULTS}

\section{Difference in the amylase values of the nectar and stomach honey}

The amount of amylase in nectar and stomach honey was measured. The results for the amount of amylase in nectar collected from areas around the different colonies at the different locations were very similar (Chengdu, CD: $\mathrm{F}_{2,6}=0.52, \mathrm{P}=0.62$; Luoping, LP: $\mathrm{F}_{2,6}=0.38, \mathrm{P}=0.69$; Menyuan, MY: $\mathrm{F}_{2,6}=3.84, \mathrm{P}=0.08$;). Similar results were obtained for stomach honey collected at $\mathrm{CD}\left(\mathrm{F}_{2,6}=3.71\right.$, $\mathrm{P}=0.09)$ and MY $\left(\mathrm{F}_{2,6}=0.09, \mathrm{P}=0.91\right)$, but not $\mathrm{LP}\left(\mathrm{F}_{2,6}\right.$ $=12.78, \mathrm{P}=0.01)$. However, the difference between sampling sites ranged from $12 \mathrm{U} / 100 \mathrm{~mL}$ at LP, followed by $\mathrm{CD}$ with $3.7 \mathrm{U} / 100 \mathrm{~mL}$ and $\mathrm{MY}$ with $3.6 \mathrm{U} / 100 \mathrm{~mL}\left(\mathrm{~F}_{2,48}=\right.$ $2578.19, \mathrm{P}<0.01)$. The amylase values recorded in honey stomachs were variable but considerably greater than that recorded for nectar. The amylase level in honey stomachs was 18.6 fold greater at $\mathrm{CD}$, five fold at MY and two fold at $\operatorname{LP}\left(\mathrm{F}_{1,48}=10551.01, \mathrm{P}<0.01\right)$ (Fig. 2).

\section{Abundance of bacteria in nectar and stomach honey}

The species of bacteria in nectar and stomach honey were identified using 16S rDNA and culturing methods. Even though the species of bacteria and concentrations of bacteria differed between colonies and for the sites sampled, the dominant bacteria were Bacillus subtilus and $B a$ - 
cillus amyloloquefaciens in the honey stomach at all three sites sampled (Table 1). These two species of Bacillus are amylase-secreting species (Welker \& Campbell, 1967).

\section{Bacillus mediated changes in amylase values}

To determine whether bacteria mediate changes in amylase values of nectar in the honey stomach of bees, we collected Bacillus from the honey stomach of bees collected at the three different locations and added them to sterile nectar. Later, the amylase values of both nectar (without bacteria) and nectar with added bacteria were measured. The amylase values of nectar with bacteria were significantly greater, 2.5 times at $\mathrm{CD}, 2.1$ times at $\mathrm{MY}$ and 1.4 times at $\mathrm{LP}\left(\mathrm{F}_{1,48}=977.885, \mathrm{P}<0.01\right)$ (Fig. 3).

\section{DISCUSSION}

The comparative analyses of amylase and bacteria in rape nectar and honey in the foregut of bees revealed that the amounts of amylase in the foreguts of bees were considerably greater than in nectar and this change is correlated with an increase in the concentration of bacteria. The addition of bacteria to nectar confirmed that the increase in amylase was due to the bacteria. These results indicate that the bacteria in the foregut of bees contribute to the processing nectar into honey.

The commonest bacteria isolated from floral nectar and the foreguts of bees were mainly Bacillus (Table 1) and different from the lactic acid bacteria of the genera $\mathrm{Lac}$ tobacillus and Bifidobacterium isolated previously (Olofsson \& Vásquez, 2008). The same species of bee and similar methods of isolating bacteria were used, however, the commonest bacteria differed. This could be due to the bees foraging for honey from different species of plants. A. mellifera pollinates and collects nectar generally from all the flowers over a large area. In the present study, we sampled only the nectar of rape at sites in Southern to Northern China chosen by traditional beekeepers for harvesting honey. Rape phenology varied depending on latitude (material and methods). The amylase values also differed at the different locations, even though the bees were foraging the same species of plant (Fig. 2). However, the commonest bacteria identified, Bacillus subtilus and Bacillus amyloloque-

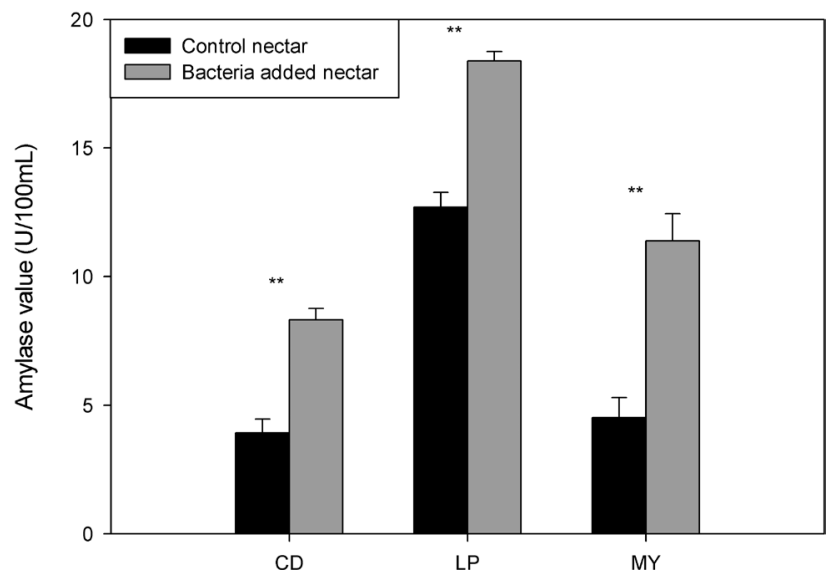

Fig. 3. Comparisons of amylase values recorded in nectar (black bar) and nectar with added bacteria (grey bar) at the three sites sampled (CD, LP and MY). ** - significant difference at $\mathrm{P}<0.01$

faciens, were similarly recorded in the honey stomachs of bees at all three sites sampled (Table 1). At all three sites, the amounts of amylase were significantly greater in the honey stomachs of bees than in nectar (Fig. 2).

Physical, chemical and biological factors can affect the microbes in nectar. Bacteria are present everywhere, with amylase producing microbes occurring in rotting starchy material, soil and even in the air (Sun et al., 2010). The hydrogen peroxide in nectar, however, could inhibit the growth of most bacteria (Carter \& Thornburg, 2004; Carter et al., 2007). Even so bacteria are present in floral nectar (Alvarez-Perez et al., 2012; Fridman et al., 2012), however, the secondary metabolites in the nectar from different plants may determine the special bacterial communities associated with different species of plants (Fridman et al., 2012). This is consistent with the results presented here, which indicate that that numbers of species and abundance of bacteria in rape nectar are both very low.

It is not possible to refute the idea that there are glands in bees that secrete amylase because we recorded a dramatic increase in amylase in the nectar in their stomachs. In addition, we found amylase producing bacteria in the foreguts of bees. This sheds new light on the question of the role gut

TABLE 1. Bacterial phylotypes recorded in the honey stomach of the honey bee, Apis mellifera.

\begin{tabular}{|c|c|c|c|c|c|}
\hline $\begin{array}{l}\text { Origin } \\
\text { of samples }\end{array}$ & Isolates & $\begin{array}{c}\text { Accession } \\
\text { numbers }\end{array}$ & $\begin{array}{c}\text { Most closely related type } \\
\text { strain and results of biochemical } \\
\text { identification }\end{array}$ & $\begin{array}{l}\text { CFU/g of isolates } \\
\text { in honey stomach } \\
(\text { Mean } \pm \mathrm{SD}) \times 10^{3}\end{array}$ & $\begin{array}{c}\text { Concentration and proportion } \\
\text { of Bacillus sp. added } \\
\text { (Total number } 1000 \mu \mathrm{L})\end{array}$ \\
\hline LP-1 & AMHSBL244 & KR057910 & B. amyloliquefaciens & $145 \pm 22$ & $10^{-5}, 320 \mu \mathrm{l}$ \\
\hline LP-2 & AMHSBL56 & KR057908 & B. amyloliquefaciens & $113 \pm 13$ & $10^{-5}, 249 \mu \mathrm{l}$ \\
\hline LP-3 & AMHSBL104 & KR057909 & B. amyloliquefaciens & $142 \pm 10$ & $10^{-5}, 313 \mu 1$ \\
\hline \multirow[t]{2}{*}{$\mathrm{CD}-1$} & AMHSBC709 & KR057915 & B. amyloliquefaciens & $109 \pm 16$ & $10^{-8}, 73 \mu \mathrm{l}$ \\
\hline & AMHSBC706 & KR057914 & B. subtilis & $132 \pm 19$ & $10^{-6}, 145 \mu 1$ \\
\hline \multirow[t]{2}{*}{ CD-2 } & AMHSBC791 & KR057917 & B. amyloliquefaciens & $131 \pm 9$ & $10^{-8}, 88 \mu \mathrm{l}$ \\
\hline & AMHSBC789 & KR057916 & B. subtilis & $156 \pm 10$ & $10^{-6}, 172 \mu 1$ \\
\hline \multirow[t]{2}{*}{ CD-3 } & AMHSBC795 & KR057918 & B. amyloliquefaciens & $159 \pm 6$ & $10^{-8}, 106 \mu \mathrm{l}$ \\
\hline & AMHSBC796 & KR057919 & B. subtilis & $112 \pm 14$ & $10^{-6}, 123 \mu \mathrm{l}$ \\
\hline MY-1 & AMHSBQ204 & KR057912 & B. subtilis & $110 \pm 19$ & $10^{-4}, 192 \mu 1$ \\
\hline MY-2 & AMHSBQ203 & KR057911 & B. subtilis & $141 \pm 9$ & $10^{-4}, 246 \mu \mathrm{l}$ \\
\hline MY-3 & AMHSBQ312 & KR057913 & B. subtilis & $170 \pm 7$ & $10^{-4}, 297 \mu \mathrm{l}$ \\
\hline
\end{tabular}


microbes in bee nutrition. This topic has been extensively reviewed, with the nutritional contribution evenly assigned to either it improving their ability to live on suboptimal diets, their digestive efficiency, acquisition of digestive enzymes or the provision of vitamins (Dillon \& Dillon, 2004). In the context of bee society, a similar study of the microbiota in bee bread and bee guts, revealed 11 bacterial phyla in bee guts and 10 in bee bread, however, the species compositions were very different. Only $7 \%$ of the species occurred in both the gut of bees and bee bread. These results indicate that specific and well adapted microbiota that are involved in the digestion of pollen occur in the guts of bees (Saraiva et al., 2015). Lee et al. (2014) also reports that three major phyla of bacteria may participate in the breakdown of complex macromolecules. In the present study, the occurrence of Bacillus in bee guts, is directly associated with the increase in amylase that occurs in nectar in the foregut of bees. The results of inoculating nectar with bacteria provided direct evidence of the involvement of gut microbiota in the rapid increase in the amylase levels in nectar (Fig. 3).

Nevertheless, bacterial inoculation resulted in a smaller increase in amylase values than that recorded in bee guts. This is probably because the gut Bacillus is better adapted to the microenvironment in the gut of bees than the experimental conditions. The microenvironment in the gut of bees is most likely determined by the variety of specialized structures present in the gut, the $\mathrm{pH}$, redox conditions, digestive enzymes and type of food ingested (Dillon \& Dillon, 2004).

\section{Application of the results of this study}

Previous studies indicate that amylase is present in several different kinds of honey and that the composition of honey changes over time. Several amylase values are used to evaluate the freshness of honey (Oddo et al., 1990). European food quality standards stipulate that the amylase value of ripe honey must be greater than $8 \mathrm{U} / 100 \mathrm{~g}$. According to the Chinese national standard, the amylase value must be greater than $4 \mathrm{U} / 100 \mathrm{~g}$ (Thrasyvoulou, 1986; Wei et al., 2012). Amylase values, however, can be affected by honey bee activity, storage temperature and differences in methods of production. Based on the current study, we now know that the microbes in bee stomachs produce amylase. Adding Bacillus to nectar may be one way of adulterating honey. Thus, we need to question the reliability of amylase values for evaluating the freshness of honey. Clearly more work needs to be done to determine a more reliable parameter for evaluating the quality of honey.

The practice of beekeepers to feed bees with pollen and sugar syrup during seasons when there is a dearth of nectar or when transporting bees before the flowering season, may also affect the quality of honey and bee health. This includes bees experiencing difficulty digesting their food after transporting them over long distances.

Furthermore, based on the results presented, we suggest beekeepers should feed bees with probiotics in order to improve their health. In the present study, when rape was flowering, Bacillus was the dominant probiotic bacteria in the stomachs of bees. There is a need for more research to determine whether the dominant probiotic bacteria in bee stomachs are flower-dependent, or bee species specific, if we are to better understand the implications for bee pollination around the world.

ACKNOWLEDGEMENTS. We would like to thank the editor of EJE and two anonymous reviewers for their kind help in improving this manuscript. We thank N.-Z. Li and S.-H. Wang (The Center of Beekeeping Management, Chengdu, China) for collecting samples. We also thank S.-F. Jian and Y.-Q. Huang (The Center of Beekeeping Management, Luoping, China) for help in organizing the honey bee colonies. We also would like to thank J. Teichroew for editing the English and improving this manuscript. This work was supported by a grant from the National System of Bee Industry and Technology Program (CARS-45-kxj14).

\section{REFERENCES}

Alvarez-Perez S., Herrera C.M. \& de Vega C. 2012: Zoomingin on floral nectar: a first exploration of nectar-associated bacteria in wild plant communities. - FEMS Microbiol. Ecol. 80: 591-602.

Carter C. \& Thornburg R.W. 2004: Is the nectar redox cycle a floral defense against microbial attack? — Trends Plant Sci. 9: 320-324.

Carter C., Healy R., Nicole M., Naqvi S.S., Ren G., Park S., Beattie G.A., Horner H.T. \& Thornburg R.W. 2007: Tobacco nectaries express a novel NADPH oxidase implicated in the defense of floral reproductive tissues against microorganisms. - Plant Physiol. 143: 389-399.

Dillon R. \& Dillon V. 2004: The gut bacteria of insects: nonpathogenic interactions. - Annu. Rev. Entomol. 49: 71-92.

Engel P., Kwong W.K. \& Moran N.A. 2013: Frischella perrara gen. nov., sp. nov., a gammaproteobacterium isolated from the gut of the honeybee, Apis mellifera. - Int. J. Syst. Evol. Microbiol. 63: 3646-3651.

Fridman S., IzhaKi I., Gerchman Y. \& Halpern M. 2012: Bacterial communities in floral nectar. - Environ. Microbiol. Rep. 4: $97-104$

Gangwar S., Gebremariam H., Ebrahim A. \& Tajebe S. 2010: Characteristics of honey produced by different plant species in Ethiopia. - Adv. Biores. 1: 101-105.

GiLliam M. 1997: Identification and roles of non-pathogenic microflora associated with honey bees. - FEMS Microbiol. Lett. 155: $1-10$.

Gilliam M., Moffett J.O. \& Kauffeld N. 1983: Examination of floral nectar of citrus, cotton, and Arizona desert plants for microbes. - Apidologie 14: 299-302.

Gupta R., Gigras P., Mohapatra H., Goswami V.K. \& Chauhan B. 2003: Microbial $\alpha$-amylases: a biotechnological perspective. - Process Biochem. 38: 1599-1616.

Henriques A.O., Beall B.W., Roland K. \& Moran C.P. Jr. 1995: Characterization of cotJ, a sigma E-controlled operon affecting the polypeptide composition of the coat of Bacillus subtilis spores. - J. Bacteriol. 177: 3394-3406.

Herrera C.M. \& Pozo M.I. 2010: Nectar yeasts warm the flowers of a winter-blooming plant. - Proc. R. Soc. (B) 277: 18271834.

Herrera C.M., García I.M. \& Pérez R. 2008: Invisible floral larcenies: microbial communities degrade floral nectar of bumble bee-pollinated plants. - Ecology 89: 2369-2376.

Herrera C.M., de Vega C., Canto A. \& Pozo M.I. 2009: Yeasts in floral nectar: a quantitative survey. - Ann. Bot. 103: 14151423. 
Herrera C.M., Pozo M.I. \& Medrano M. 2013: Yeasts in nectar of an early-blooming herb: sought by bumble bees, detrimental to plant fecundity. - Ecology 94: 273-279.

Howell E. 1985: Enzyme Nutrition. Avery, Wayne, NJ, 177 pp.

Lee F.J., Rusch D.B., Stewart F.J., Mattila H.R. \& Newton I.L. 2014: Saccharide breakdown and fermentation by the honey bee gut microbiome. - Environ. Microbiol. 17: 796-815.

Oddo L.P., Baldi E. \& Accorti M. 1990: Diastatic activity in some unifloral honeys. - Apidologie 21: 17-24.

Olofsson T. \& VÁsquez A. 2008: Detection and identification of a novel lactic acid bacterial flora within the honey stomach of the honeybee Apis mellifera. - Curr. Microbiol. 57: 356-363.

Pozo M.I., Herrera C.M. \& Bazaga P. 2011: Species richness of yeast communities in floral nectar of southern Spanish plants. - Microb. Ecol. 61: 82-91.

Rinaudo M., Ponzetto C., Vidano C. \& Marletto F. 1973: The origin of honey amylase. - Comp. Biochem. Physiol. (B) 46: 253-256.

Saraiva M.A., Zemolin A.P.P., Franco J.L., Boldo J.T., Stefenon V.M., Triplett E.W., de Oliveira Camargo F.A. \& Roesch L. F.W. 2015: Relationship between honeybee nutrition and their microbial communities. - Anton. Leeuw. Int. J. Microbiol. 107: 921-933.
SNYDER A. 2009: Bacillus amyloliquefaciens Strain. US patent application US 12/492,816. Publication no. US20090324533.

Sun H., Zhao P., Ge X., Xia Y., Hao Z., Liu J. \& Peng M. 2010: Recent advances in microbial raw starch degrading enzymes. - Appl. Biochem. Biotech. 160: 988-1003.

Thrasyvoulou A. 1986: Use of HMF and diastase as criteria of quality of Greek honey. - J. Apicult. Res. 25: 186-195.

Wang M., Xu H., Yin G., Zhao W. \& He S. 2014: Diversity of bacteria in the honey stomach of Apis cerana and Apis mellifera during the rape blooming period. - Chin. J. Appl. Entomol. 51: 1567-1575.

Wei G.-X., Huang J.-K. \& YAng J. 2012: Honey safety standards and its impacts on China's honey export. - J. Integr. Agric. 11: 684-693.

WeLKeR N. \& CAmpBell L.L. 1967: Comparison of the $\alpha$-amylase of Bacillus subtilis and Bacillus amyloliquefaciens. - J. Bacteriol. 94: 1131-1135.

Winston M.L. 1987: The Biology of the Honey Bee. Harvard Univ Press, Cambridge, MA, pp. 46-71, 169-180.

Received April 30, 2015; revised and accepted July 27, 2015 Prepublished online September 22, 2015 